\title{
O idoso enquanto narrador - contemporâneo?
}

Dra. Fátima Ferretti

FisiSenectus. Unochapecó Ano 7, n. 2 - Jul/Dez. 2019 p. 1-2

0 que é e a que nos remeteu pensar este tema vinculado à contemporaneidade? Estaria a arte de narrar conforme posto por Walter Benjamin em "vias de extinção"? Poderia a população idosa contribuir efetivamente no resgate e no debate do que está posto como papel social para os velhos na atualidade? Inicialmente, para aprofundar este diálogo resgatamos o texto do filósofo italiano Giorgio Agamben ${ }^{1}$ sobre o que é ser contemporâneo.

Agamben ${ }^{1}$ propõe que para ser contemporâneo do seu tempo é necessário que guardemos uma relação ambivalente com o presente, não simplesmente de adesão cega aos fatos, nem de completa negação deles, de uma radical contra-facticidade. Contemporâneo seria aquele que ao refletir sobre o presente procura o fazer com certo distanciamento. Nas palavras do autor a contemporaneidade, portanto, é uma singular relação com o próprio tempo, que adere a este e, ao mesmo tempo, dele toma distâncias, logo, aqueles que coincidem muito plenamente com sua época, que em todos os aspectos a esta aderem perfeitamente, não são contemporâneos porque, exatamente por isso, não conseguem vê-la, não podem manter fixo o olhar sobre ela ${ }^{1}$.

Outra dimensão da condição do contemporâneo é a relação com o passado. Somente a capacidade de ver no presente as pegadas do arcaico que resistem ao tempo é que permite uma cabal compreensão da epocalidade em que se vive, inclusive (ou talvez principalmente) com relação ao passado não-vivido que reclama que sua potência seja atualizada.
Thompson ${ }^{2}$ ao tratar da história oral enfatizou que o resgate de memórias de idosos, registrando seu passado, devolve às pessoas que vivenciaram esta história um lugar fundamental, já que agora as testemunhas podem retratar um fato ou evento como uma construção mais realista, mais viva, inclusive produzindo contestações de registros dados como verdadeiros.

Aganbem $^{1}$ diria, que para o contemporâneo não basta simplesmente ter um confronto aberto e ambíguo com o que nos acontece, enquanto atitude que deve caracterizar a relação do ser humano com a sua época, mas também ter a capacidade de transcender a presentidade, conseguir ver o escuro na luz e a luz no escuro para transcendê-la, a partir de uma conexão com o presente e, de maneira singular com o passado. Para ele o contemporâneo não é apenas aquele que, percebendo o escuro do presente, nele apreende a resoluta luz; é também aquele que, dividindo e interpolando o tempo, está à altura de transformá-lo e de colocá-lo em relação com os outros tempos, de nele ler de modo inédito a história, de 'citá-la' segundo uma necessidade que não provém de maneira nenhuma do seu arbítrio, mas de uma exigência à qual ele não pode responder.

A partilha de diferentes experiências, por meio da história oral, conforme Benjamin ${ }^{3}$ traz, são a fonte de muitos narradores. O narrador participa da vida do ouvinte socializando experiências

\section{Fisiß̌enectus}


por meio de uma distância temporal e espacial, é aquele que também dá conselhos aos ouvintes. Isto é, por meio do que podemos chamar de sabedoria prática, o narrador, longe de dar explicações sobre os acontecimentos aos seus ouvintes, ele os faz adentrar, conforme o conto de Leskov, em suas próprias problemáticas. Para tanto, há a necessidade de verbalizar a situação que espera poder se aconselhar, isto é, a troca de experiências e o aconselhamento têm como necessidade "saber narrar a história".

Ao dar voz a múltiplos e diferentes narradores tornamos o resgate do passado uma atividade mais democrática e contemporânea, já que permite (re)construir a história por meio dos relatos das vivências e experiências daqueles que participaram de um determinado período, mediante registro de reminiscências das memórias individuais; se faz, a reinterpretação do passado ${ }^{2}$.

Dessa forma, quando os idosos relatam o que é ser velho na atualidade, o que entendem por uma vida boa e saúde no tempo do agora, ou como o trabalho se constituiu numa marca central de sua identidade, o fazem tomando um distanciamento do tempo passado, pois nos privilegiam confidenciando os sentidos e significados do que foi sua vida, vinculada ao relato da história, da memória, do vivido e não vivido, logo são essencialmente narradores.

Pensando o papel do idoso como narrador que traz a luz as problemáticas de se viver a veIhice em épocas tão líquidas, Agamben ${ }^{1}$ reforça que que a via de acesso ao presente tem a forma de uma arqueologia que não regride, no entanto, a um passado remoto, mas a tudo aquilo que no presente não podemos em nenhum caso viver e, restando não vivido, é incessantemente relançado para a origem... Já que o presente não é outra coisa senão a parte do não vivido em todo o vivido e, a atenção dirigida a este não-vivido é a vida do contemporâneo, ser um ator social contemporâneo significa, nesse sentido, voltar-se a refletir sobre um presente em que jamais estivemos.

Compreendemos o idoso enquanto um narrador conforme Benjamin ${ }^{3}$ situa em seu texto, uma figura que está entre os mestres e os sábios, que sabe dar conselhos: não para alguns casos, mas para muitos casos, já que viveram muitos invernos e verões, o que os fez ver, viver, sentir e apreender com uma diversidade de eventos e tempos históricos. 0 sábio pode recorrer a um acervo de toda uma vida, que não inclui apenas a própria experiência, mas em grande parte a experiência alheia. O narrador assimila à sua substância mais íntima aquilo que sabe por ouvir dizer. Seu dom é poder contar sua vida; sua dignidade é contá-la inteira. Conforme Bosi ${ }^{4}$ mais que um documento unilinear, a narrativa mostra a complexidade do acontecimento, é a via privilegiada para chegar até o ponto de articulação da história com o cotidiano dos humanos.

Benjamin ${ }^{3}$ ainda diria que quem presta atenção a uma estória, está em companhia de alguém; mesmo aquele que a lê participa dessa companhia, assim a narrativa revelará sempre a marca do narrador, assim como a mão do artista é percebida, por exemplo, na sua obra.

Envelhecer no mundo contemporâneo se dá de forma diferente para cada ser humano, numa relação de muitas dimensões e complementaridade de fatores. Cada ser humano se percebe no tempo do novo estado de ser situado em um tempo transcorrido da vida, de acordo com indicativos sociais, históricos, culturais e ambientais impostos pela própria sociedade a qual pertence. Beauvoir ${ }^{5}$ "diria que como todas as situações humanas, a velhice tem uma dimensão existencial, que modifica a relação do indivíduo com o tempo e, portanto, sua relação com o mundo e com a própria história".

Para compreendermos a realidade e a significação da velhice seria indispensável examinarmos o lugar que é destinado aos seres humanos mais velhos, que representação se faz deles em diferentes tempos, em diferentes lugares ${ }^{5}$. 0 interesse desse confronto é que permitirá, senão dar, ao menos registrar algumas questões essenciais a serem problematizadas em outros ensaios: 0 que há de inelutável na condição dos velhos? Em que medida a sociedade é responsável por ela? Qual o papel social desse ser humano? Nesse movimento defendemos a ideia que dialogar e sentar aos pés dos idosos para ouvir suas narrativas sobre 0 processo de nascer e viver em determinado lugar e ambiente, constitui-se num processo intenso de dar voz àqueles que vivem este momento existencial, numa condição de minoria, de legitimar a sua 
participação na história e, ainda, refletir sobre sua condição.

O modo como cada pessoa envelhece está fortemente relacionado com o contexto social onde está inserido e a sua história de vida. 0 que as pessoas almejam é viver bem, com qualidade de vida, independentemente de sua idade. A convivência com as pessoas com mais verões e invernos de vida nos dá a oportunidade de melhor compreender essa fase da vida.

Viver em determinado tempo e partilhar a essência de suas vidas, pelo ato de narrar, confere reconhecimento e valoração ao papel social destes idosos. Ao narrar suas histórias estes realizam um movimento de lançar luz sobre o passado e de transcender a sua epocalidade, bem como, Agamben postula - aqueles que coincidem muito plenamente com a época, que em todos os aspectos a esta aderem perfeitamente, não são contemporâneos porque, exatamente por isso, não conseguem vê-la. Quem já sentou aos pés de um idoso, para ouvi-los enquanto narradores, num movimento de acolher seus relatos e produzir reflexões, diria, com certeza, que muitos não "coincidem plenamente" com sua época, portanto poderíamos inferir a estes que se constituem como atores sociais contemporâneos. Este editorial, simplesmente lançou sementes em um solo fértil, que com algum regar e cuidar, pode promover outras reflexões e debates, mas que que por hora estão postos como um movimento inicial e inacabado do "ato de tecer" uma linda peça que aquece e protege em "tempos frios".

\section{Referências}

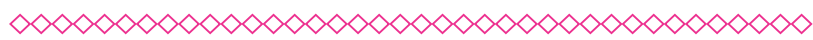

1. Agamben G. O que é contemporâneo? E outros ensaios. Chapecó, Santa Catarina: Argos; 2009.

2. Thompson P. A voz do passado: história oral. 3. ed. São Paulo: Paz e Terra; 2002.

3. Benjamin W. O Narrador: Considerações sobre a obra de Nikolai Leskov. In: Benjamin W. Obras escolhidas: magia e técnica, arte e política. Trad. Sérgio Paulo Rouanet. 3. ed. Vol. 1. São Paulo: Ed. Brasiliense; 2012. p. 197-221.

4. Bosi E. O tempo vivo da memória: ensaios de Psicologia Social. 2. ed. São Paulo: Ateliê Editorial; 2004.

5. Beauvoir S. A velhice. 6.ed. Rio de Janeiro: Nova Fronteira; 1990. 